\title{
Pengaruh Pemberian Ekstrak Etanol Buah Sirsak (Annona muricata L.) Pada Kadar Kolesterol Low Density Lipoprotein (LDL) Tikus Putih (Rattus norvegicus) Hiperkolesterolemia
}

\section{The Effect of Soursop Fruit Ethanol Extract (Annona Muricata L.) on Low Density Lipoprotein (LDL) Cholesterol Levels White Rat (Rattus Norvegicus) Hipercolesterolemia}

\author{
Siti Fatimah*, Desto Arisandi, Sismawati \\ Program Studi D-III Analis Kesehatan, STIKes Guna Bangsa \\ Jl. Padjajaran No.Kel, Ngringin, Condongcatur, Kec. Depok, Kabupaten Sleman, \\ Daerah Istimewa Yogyakarta 55283, Indonesia \\ *Corresponding Author: siti.fatimah.gunabangsa@gmail.com
}

Received: Agustus 23, 2019; Revise: October 21., 2019; Accepted: December 20, 2019

DOI : https://doi.org/10.31001/biomedika.v12i2.637

\begin{abstract}
ABSTRAK
Penyebab Penyakit jantung koroner (PJK) adalah peningkatan kadar kolesterol di dalam darah, sehingga berisiko terjadi penyumbatan pada pembuluh darah (aterosklerosis). Kolesterol LDL yang banyak terdapat di dalam aliran darah akan tertimbun di dalam pembuluh darah arteri dan berpotensi mengakibatkan penyumbatan. Ekstrak buah sirsak mengandung senyawa antioksidan seperti alkaloid, tannin, saponin, flavonoid dan polifenol yang sangat dibutuhkan untuk meningkatkan daya tahan tubuh dan mencegah berbagai penyakit yang masuk ke dalam tubuh. Telah dilakukan penelitian untuk mengetahui pengaruh pemberian ekstrak etanol buah Sirsak (Annona Muricata L.) pada Kolesterol Low Density Lipoprotein (LDL) tikus putih (Rattus Norvegicus) hiperkolesterolemia. Penelitian ini dilakukan secara eksperimental dengan 10 ekor tikus putih jantan (Rattus Novergicus, L.), berumur 2-3 bulan dengan berat 150-200 g, yang dibagi dalam 2 kelompok yaitu kelompok kontrol dan kelompok perlakuan. Induksi hiperkolesterolemia dilakukan dengan pemberian makanan diet lemak tinggi selama 7 hari. Ekstrak etanol buah sirsak diberikan secara sonde pada kelompok perlakuan dengan dosis 3,6 $\mathrm{mg} / 200 \mathrm{gBB} /$ hari selama 14 hari dan pengukuran kadar kolesterol LDL dilakukan pada hari ke 16 dan 30 dengan metode pemeriksaan CHOD-PAP. Data dianalisis dengan uji Paired t-test. Hasil penelitian menunjukkan kadar kolesterol LDL pada kelompok perlakuan menunjukkan sebanyak 5 tikus mengalami penurunan, rerata penurunan sebesar $32,49 \mathrm{mg} / \mathrm{dl}$ sedangkan pada kelompok kontrol sebanyak 2 tikus mengalami penurunan, rerata penurunan sebesar $0,76 \mathrm{mg} / \mathrm{dl}$. Ada perbedaan yang signifikan $(\mathrm{p}<0.05)$ pada perubahan kadar kolesterol LDL pada kelompok perlakuan. Pemberian ekstrak buah sirsak dengan 3,6 mg/200gBB/hari selama 14 hari dapat menurunkan kadar kolesterol LDL tikus hiperkolesterolemia. Kata kunci: tikus hiperkolesterolemia, LDL, ekstrak etanol buah sirsak
\end{abstract}

\begin{abstract}
The cause of Coronary heart disease is an increase caused due to increased cholesterol levels in the blood, so there is a risk of blockage in the blood vessels (atherosclerosis). LDL cholesterol which is abundant in the bloodstream will accumulate in the arteries and potentially cause blockages. Ethanol extract of soursop fruit (Annona Muricata L.) contains antioxidant compounds such as alkaloids, tannins, saponins, flavonoids and polyphenols that are needed to increase endurance and prevent various diseases that enter the body. Research has been conducted to determine the effect of soursop fruit ethanol extract (Annona Muricata L.) on Low Density Lipoprotein (LDL) cholesterol levels white Rat (Rattus Norvegicus) hipercolesterolemia. This research was conducted experimentally with 10 male white rats (Rattus Novergicus, L.), aged 2-3 months with a weight of 150-200 g, which were divided into 2 groups: the control group and the treatment group. Hypercholesterolemia induction is done by giving high fat diet foods for 7 days. Soursop fruit ethanol extract was given in a sonde to the treatment group at a dose of
\end{abstract}


$3.6 \mathrm{mg} / 200 \mathrm{gBB} /$ day for 14 days and measurements of LDL cholesterol levels were carried out on days 16 and 30 by the CHOD-PAP examination method. Data were analyzed by Paired t-test. The results showed LDL cholesterol levels in the treatment group showed that as many as 5 mice decreased, the mean decreased by $32.49 \mathrm{mg} / \mathrm{dl}$ while in the control group as many as 2 mice decreased, the mean decreased by $0.76 \mathrm{mg} / \mathrm{dl}$. There was a significant difference $(p<0.05)$ in changes in LDL cholesterol levels in the treatment group. Soursop fruit etanol extract with $3.6 \mathrm{mg} / 200 \mathrm{gBB} /$ day for 14 days can reduce LDL cholesterol levels in hypercholesterolemia rats.

Key word: hypercholesterolemia rats, $L D L$, soursop fruit ethanol extract

\section{PENDAHULUAN}

Menurut

Kementrian Kesehatan

Departemen

Indonesia Tahun 2014, prevalensi penyakit jantung koroner di Indonesia berdasarkan diagnosis dokter sebesar 0,5\% atau diperkirakan sekitar 883.447 orang. Penyakit jantung koroner (PJK) diakibatkan karena peningkatan kadar kolesterol di dalam darah, sehingga beresiko terjadi penyumbatan pada pembuluh darah (aterosklerosis) (Nilawati, dkk., 2008).

Aterosklerosis ditandai dengan penebalan dinding pembuluh darah arteri, sehingga terjadi penyempitan lumen pembuluh darah, merangsang pembentukan pembekuan darah yang menghambat aliran darah ke jantung, otak, dan jaringan paru-paru (Linder, 2010). Peningkatan kadar kolesterol di dalam darah (hiperkolesterolemia) merupakan salah satu faktor resiko yang paling utama terjadi PJK (Anies, 2015).

Antioksidan merupakan senyawa yang memiliki berat molekul kecil yang mampu mencegah pembentukan radikal bebas dengan cara reaksi oksidasi untuk menghambat terjadinya kerusakan sel pada penyakit degeneratif. Antioksidan berupa enzim (superoksida dismutase, katalase, dan glutation peroksidase), vitamin (vitamin $\mathrm{E}, \mathrm{C}, \mathrm{A}$ dan $\beta$-karoten) dan senyawa lain (flavonoid, albumin, bilirubin, dan seruloplasmin) (Winarsi, 2009).

Flavonoid merupakan sekelompok besar senyawa polifenol tanaman yang tersebar luas dalam berbagai bahan makanan (sayuran dan buah-buahan) dalam berbagai konsentrasi (Winarsi, 2009). Flavonoid berperan sebagai antioksidan pereduksi LDL di dalam tubuh, menaikkan densitas reseptor LDL di hati dan meningkatkan Apolipoprotein B. Flavonoid juga berperan sebagai senyawa yang mereduksi trigliserida dan meningkatkan HDL dan mampu mengaktifkan sistem multi enzim seperti sitokrom-450 dan b5 yang mempengaruhi metabolisme lipid dan asam empedu (Agustina dalam Risky, 2014).

Buah sirsak diketahui memiliki banyak manfaat yang mengandung senyawa seperti vitamin $\mathrm{C}$, karbohidrat, dan lemak. Ekstrak buah sirsak mengandung senyawa antioksidan seperti alkaloid, glikosida, protein, saponin, tanin, flavonoid dan polifenol. Berdasarkan hal tersebut perlu dilakukan penelitian tentang ekstrak etanol buah sirsak (Abbas dkk., 2015).

Penelitian ekstrak etanol buah sirsak sebagai penurun kolesterol LDL belum pernah dilakukan. Penelitian yang pernah dilakukan Tia dkk (2014) tentang pengaruh berbagai dosis jus buah sirsak 
terhadap penurunan kolesterol LDL Tikus dislipidemia dan penelitian Dharma (2014) tentang Pengaruh Ekstrak Etanol Daun Sirsak (Annona muricata L.) Terhadap Kadar LDL pada Tikus Putih Jantan.

\section{METODE PENELITIAN}

Jenis penelitian ini bersifat true experiment dengan desain pre test and post test group design with control untuk mengetahui pengaruh pemberian ekstrak etanol buah sirsak.

\section{Alat dan Bahan}

Kandang hewan coba, timbangan analitik (ADAM), spektrofotometer SP 300 (Optima) UV-Vis, kuvet, centrifuge, tabung mikrohematokrit, juicer (AirLux), sonde, mikropipet 10-100 $\mu 1$ dan 100-1000 $\mu 1$, tip warna kuning dan biru, rak tabung, dan rotary evaporator, Serum tikus putih, etanol $70 \%$, reagen LDL precipitant, kertas saring, reagen kolesterol, reagen standar kolesterol, $\mathrm{NaCl} 0,9 \%$, pakan tinggi lemak terdiri dari $1 \mathrm{~kg}$ lemak sapi, 4 butir kuning telur ayam dan $4 \quad \mathrm{~kg}$ pakan standar (perbandingan 1:4:4), buah sirsak yang sudah tua dan masak.

\section{Prosedur Penelitian \\ Persiapan hewan percobaan}

Sebanyak 10 ekor tikus putih (Rattus Novergicus, L.) jantan masingmasing 5 ekor tikus putih untuk kelompok kontrol positif (LDL tinggi), dan 5 ekor tikus putih sebagai kelompok perlakukan kemudian ditimbang berat badannya. Sepuluh ekor tikus putih diadaptasi dalam kondisi laboratorium selama 7 hari dengan diberi pakan standar dan akuades kemudian dilakukan pengukuran kadar LDL darah menggunakan metode CHOD-PAP pada spektrofotometer. Pada hari ke 8 Kelompok kontrol positif dan kelompok perlakuan diberi pakan tinggi lemak \pm 20 gram/ekor/hari dan minum akuades selama 7 hari.

\section{Pembuatan ekstrak etanol buah sirsak}

Daging buah sirsak dihancurkan dengan juicer hingga didapatkan sarinya, diambil sebanyak $300 \mathrm{ml}$ ditambah pelarut etanol $70 \%$ sebanyak $3000 \mathrm{ml}$ dan dimasukkan ke dalam wadah yang tertutup, dibiarkan selama 2 hari (pengulangan 2 kali). Maserat etanol diuapkan dengan rotary evaporator suhu $60^{\circ} \mathrm{C}$ dengan kecepatan 110 rpm sampai diperoleh ekstrak etanol kental

\section{Pemberian ekstrak buah sirsak}

Dosis disesuaikan dengan penggunaan pada manusia dalam mengkonsumsi 1 gelas jus sirsak (200 ml) (Rahman dkk., 2014). Sebanyak 0,2 gram rendemen sampel kemudian dikonversi ke dosis hewan uji 0,018 (Kusumawati, 2016) sehingga dosis yang diberikan pada tikus yaitu 3,6 mg/200gramBB/hari. Ekstrak etanol buah sirsak diberikan pada hari ke 16 pada kelompok perlakuan selama 14 hari. 
Pengambilan spesimen darah dan pemeriksaan $L D L$

Pengambilan darah dilakukan pada vena tikus putih melalui sinus orbitalis menggunakan tabung mikrokapiler. Darah yang telah keluar ditampung. Darah didiamkan selama 30 menit kemudian disentrifugasi dengan kecepatan 4000 rpm untuk mendapatkan serum.

\section{Pemeriksaan kadar LDL dilakukan dengan cara kerja berikut ini}

a. Prosedur pemeriksaan kadar kolesterol total

Tabel 1. Prosedur Pemeriksaan Kadar Kolesterol Total

\begin{tabular}{cccc}
\hline & Blanko $(\boldsymbol{\mu L})$ & Standar $(\boldsymbol{\mu L})$ & Sampel $(\boldsymbol{\mu L})$ \\
\hline Serum & - & - & 10 \\
Standar kolesterol & - & 10 & - \\
Reagen kolesterol & 1.000 & 1.000 & 1.000
\end{tabular}

Reagen dicampur, kemudian diinkubasi 20 menit pada suhu ruang dan diukur absorbansinya menggunakan spektrofotometer pada panjang gelombang $546 \mathrm{~nm}$.

b. Pengenceran standar kolesterol

Diencerkan dengan $\mathrm{NaCl}$ 0,9\% fisiologis dengan perbandingan 1:10.

c. Pembuatan supernatan, Reagen presipitan diambil sebanyak $1.000 \mu \mathrm{L}$ dimasukkan ke tabung reaksi ditambahkan serum sebanyak $100 \mu \mathrm{L}$, kemudian diinkubasi 15 menit suhu ruang. Campuran dicentrifuge 20 menit kecepatan 2500 rpm kemudian supernatan dipisahkan

d. Prosedur pemeriksaan kadar LDL

Tabel 2. Prosedur Pemeriksaan Kadar Kolesterol LDL

\begin{tabular}{cccc}
\hline & Blanko $(\boldsymbol{\mu L})$ & Standar $(\boldsymbol{\mu L})$ & Sampel $(\boldsymbol{\mu L})$ \\
\hline Reagen kolesterol & 1.000 & 1.000 & 1.000 \\
Standar kolesterol & - & 100 & - \\
Supernatan & - & - & 100
\end{tabular}

Reagen dicampur, diinkubasi 20 menit pada suhu ruang dan absorbansi dibaca menggunakan spektrofotometer pada panjang gelombang $546 \mathrm{~nm}$.

Tahap Perhitungan Hasil

Rumus perhitungan Kadar kolesterol LDL darah dengan metode CHOD-PAP sebagai berikut :

Kolesterol Total $=\frac{\text { A sampel }}{\text { A standar }} \times 200\left(\frac{\mathrm{mg}}{\mathrm{dl}}\right)$

Kolesterol Supernatan $=\frac{\text { A supernatan }}{\text { A standar }} \times 200\left(\frac{\mathrm{mg}}{\mathrm{dl}}\right)$

Kadar LDL $=$ Kolesterol Total - Kolesterol Supernatan 


\section{Analisis Data}

Hasil pengukuran kemudian dianalisis uji normalitas menggunakan KolmogorovSmirnov, selanjutnya dilakukan uji statistika paired-samples t-test dengan taraf signifikan 0,05 dan nilai signifikan diterima bila $\mathrm{P}<0,05$.

\section{HASIL DAN PEMBAHASAN}

Hasil perhitungan selisih kadar kolesterol LDL tikus k sebelum dan sesudah pemberian ekstrak etanol buah sirsak dapat terdapat pada tabel 5 .

Tabel 3. Hasil Kadar Kolesterol Total dan Kadar Kolesterol LDL Pre test

\begin{tabular}{cccc}
\hline Tikus & $\begin{array}{c}\text { Kadar kolesterol } \\
\text { total }(\mathbf{m g} / \mathbf{d l})\end{array}$ & $\begin{array}{c}\text { Kadar kolesterol } \\
\text { supernatan }(\mathbf{m g} / \mathbf{d l})\end{array}$ & $\begin{array}{c}\text { Kadar kolesterol } \\
\text { LDL }(\mathbf{m g} / \mathbf{d l})\end{array}$ \\
\hline K1 & 209,62 & 71,13 & 138,50 \\
K2 & 206,87 & 72,54 & 134,34 \\
K3 & 204,12 & 71,83 & 132,29 \\
K4 & 213,75 & 73,24 & 140,51 \\
K5 & 218,56 & 76,76 & 141,80 \\
P1 & 216,49 & 75,35 & 141,14 \\
P2 & 202,75 & 80,99 & 121,76 \\
P3 & 206,19 & 76,76 & 129,43 \\
P4 & 212,37 & 73,94 & 138,43 \\
P5 & 207,56 & 78,87 & 128,69 \\
\hline
\end{tabular}

Tabel 4. Hasil Kadar Kolesterol Total dan Kadar Kolesterol LDL Post test

\begin{tabular}{cccc}
\hline Tikus & $\begin{array}{c}\text { Kadar kolesterol } \\
\text { total } \mathbf{( m g / d l )}\end{array}$ & $\begin{array}{c}\text { Kadar kolesterol } \\
\text { supernatan }(\mathbf{m g} / \mathbf{d l})\end{array}$ & $\begin{array}{c}\text { Kadar kolesterol } \\
\text { LDL( mg/dl) }\end{array}$ \\
\hline K1 & 210,95 & 73,64 & 137,31 \\
K2 & 207,30 & 72,87 & 134,43 \\
K3 & 205,84 & 72,09 & 133,75 \\
K4 & 214,60 & 74,42 & 140,18 \\
K5 & 221,17 & 77,52 & 143,65 \\
P1 & 145,26 & 49,61 & 95,64 \\
P2 & 152,55 & 54,26 & 98,29 \\
P3 & 148,91 & 52,71 & 96,19 \\
P4 & 161,31 & 50,39 & 110,93 \\
P5 & 153,28 & 51,94 & 101,35 \\
\hline
\end{tabular}

Dari hasil pengukuran kadar kolesterol LDL tikus, setelah diberikan perlakuan ekstrak etanol buah sirsak 3,6 mg/200gramBB/hari selama 14 hari sebanyak 3 tikus (K2, K3 dan K5) telah mengalami peningkatan kadar kolesterol LDL dan sebanyak 7 tikus (K1, K4, P1, P2, P3, P4, dan P5) mengalami penurunan kadar kolesterol LDL. Rata-rata kadar kolesterol LDL sebelum dan sesudah pemberian ekstrak etanol buah sirsak terdapat pada tabel 6 . 
Tabel 5. Selisih kadar kolesterol LDL sebelum dan sesudah perlakuan

\begin{tabular}{cccc}
\hline Tikus & $\begin{array}{c}\text { Kadar kolesterol LDL } \\
\text { sebelum pemberian ekstrak } \\
\text { etanol buah sirsak (mg/dl) }\end{array}$ & $\begin{array}{c}\text { Kadar kolesterol LDL } \\
\text { sesudah pemberian ekstrak } \\
\text { etanol buah sirsak (mg/dl) }\end{array}$ & $\begin{array}{c}\text { Selisih Pre test } \\
\text { dan post test } \\
\text { (mg/dl) }\end{array}$ \\
\hline K1 & 138,50 & 137,31 & 1,19 \\
K2 & 134,34 & 134,43 & 0,09 \\
K3 & 132,29 & 133,75 & 1,46 \\
K4 & 140,51 & 140,18 & 0,33 \\
K5 & 141,80 & 143,65 & 1,85 \\
P1 & 141,14 & 95,64 & 45,50 \\
P2 & 121,76 & 98,29 & 23,47 \\
P3 & 129,43 & 96,19 & 33,23 \\
P4 & 138,43 & 110,93 & 27,50 \\
P5 & 128,69 & 101,35 & 27,43 \\
\hline
\end{tabular}

Keterangan: $\mathrm{K}=$ kontrol, $\mathrm{P}=$ Perlakuaan

Tabel 6. Rata-rata Kadar Kolesterol LDL Sebelum dan Sesudah Perlakuan selama 14 hari

\begin{tabular}{lcc}
\hline Variabel & $\begin{array}{l}\text { Kontrol }(\mathbf{n}=5) \\
\text { Mean } \pm \text { SD }\end{array}$ & $\begin{array}{l}\text { Perlakuan }(\mathbf{n}=5) \\
\text { Mean } \pm \text { SD }\end{array}$ \\
\hline Kadar kolesterol $(\mathrm{mg} / \mathrm{ml})$ & & \\
sebelum & $137,49 \pm 4,05$ & $131,89 \pm 7,86$ \\
Sesudah & $137,86 \pm 4,12$ & $101,48 \pm 6,26$ \\
$\mathrm{p}$ & 0,542 & 0,001 \\
\hline
\end{tabular}

Pada tabel 6 menunjukkan tikus kelompok kontrol mengalami kenaikan kadar kolesterol LDL namun tidak signifikan $(\mathrm{p}>0,05)$ dan pada kelompok perlakuan setelah pemberian ekstrak etanol buah sirsak $3,6 \mathrm{mg} / 200$ gramBB/hari selama 14 hari mengalami penurunan kadar kolesterol LDL yang signifikan $(\mathrm{p}<0,05)$, sehingga dapat dikatakan ekstrak etanol buah sirsak dosis 3,6 $\mathrm{mg} / 200$ gramBB/hari efektif dapat menurunkan kadar kolesterol LDL pada tikus hiperkolesterolemia. Tabel 6 diperoleh ratarata kadar kolesterol LDL tikus putih dengan pemberian ekstrak etanol buah sirsak dosis $3,6 \mathrm{mg} / 200 \mathrm{gramBB} / \mathrm{hari}$ yaitu $131,89 \mathrm{mg} / \mathrm{dl}$ menjadi 100,48 mg/dl. Penurunan kadar kolesterol LDL sebesar $31,41 \quad \mathrm{mg} / \mathrm{dl}$ $(23,81 \%)$.

Salah satu faktor utama terjadinya arterosklerosis yaitu kolesterol LDL tinggi yang selanjutnaya dapat mengakibatkan berbagai penyakit kardiovaskuler diantaranya jantung koroner dan stroke. Kolesterol dalam darah yang tinggi menyebabakan terbentuknya plak yang akan menyumbat saluran pembuluh darah. Keadaan ini mengakibatkan sebagian fungsi organ akan terhenti atau tidak berfungsi dengan baik (Kurniadi dan Nurrahmani, 2014).

Penurunan kadar kolesterol pada penelitian ini karena pemberian ekstrak buah sirsak yang mengandung antioksidan seperti alkaloid, tannin, saponin, flavonoid dan polifenol. Flavonoid diketahui berfungsi menghambat oksidasi LDL yang telah dimodifikasi makrofag dengan mengurangi $\alpha$-tocophenol yang terkandung dalam partikel LDL, alkaloid dengan cara menghambat enzim lipase pancreas dan tanin akan bereaksi dengan mukosa protein (Abbas, dkk., 2015).

Berdasarkan hasil penelitian yang dilakukan oleh Dharma, dkk (2014) diketahui bahwa ekstrak daun sirsak dapat menurunkan 
kadar kolesterol LDL dengan pemberian dosis $2 \mathrm{mg} / 20 \mathrm{gBB}$ sebesar $31,42 \%$, dosis 6 $\mathrm{mg} / 20 \mathrm{gBB}$ sebesar $39,53 \%$ dan $18 \mathrm{mg} / 20 \mathrm{gBB}$ sebesar $50,76 \%$. Penelitian yang dilakukan oleh Tia, dkk (2014) menunjukkan bahwa jus buah sirsak dapat menurunkan kadar kolesterol LDL dengan dosis $0,9 \mathrm{~g} / 200 \mathrm{gBB}$ sebesar 46,19\%, 1,8 g/200gBB sebesar $52,30 \%$ dan $2,7 \mathrm{~g} / 200 \mathrm{gBB}$ sebesar $61,62 \%$. Hasil penelitian Firmansyah dkk (2016) Ekstrak etanol dan ekstrak kloroform daun sirsak (Annona muricata) dapat menurunkan kadar glukosa dan kolesterol, walaupun hasilnya belum yang sama dengan glibenklamid. Penelitian Yuniarti, dkk (2016), ekstrak air daun sirsak mempengaruhi kadar kolestrol darah tikus model obese dengan efek yang sama baik dengan simvastatin. Hasil penelitian Uneputty dkk (2013), pemberian infusa daun sirsak berpotensi menurunkan kadar kolesterol darah. Hasil penelitian Wurdianing,, dkk (2014), pemberian ekstrak daun sirsak secara signifikan dapat menurunkan kadar kolesterol total dan meningkatkan kadar kolesterol HDL. Hasil penelitian Posangi dkk ( 2012), ekstrak daun sirsak efektif dapat menurunkan kadar kolesterol total sesuai dengan dosis yang diberikan. Hasil penelitian Rofida dkk (2015) menunjukkan bahwa pemberian ekstrak etanol daun Annona squamosa L. pada tikus hiperlipidemia, dapat menurunkan kadar kolesterol LDL pada dosis $0,25 \mathrm{mg} / \mathrm{gram} \mathrm{BB}$ tikus.

Penelitian yang dilakukan dengan pemberian ekstrak etanol buah sirsak dapat menurunkan kadar kolesterol LDL tikus putih dengan dosis 3,6 mg/200gBB/hari sebesar $23,81 \%$. Hal ini menunjukkan bahwa ekstrak etanol buah sirsak, jus buah sirsak dan ekstrak etanol daun sirsak dapat menurunkan kadar kolesterol LDL. Penelitian ini menggunakan tikus putih Rattus norvegicus sebanyak 10 ekor berdasarkan ketentuan WHO (WHO, 2001) sebagai hewan uji.Usia tikus yang digunakan yaitu kisaran 2-3 bulan karena dikatakan dewasa. Rata-rata berat badan tikus yang digunakan untuk penelitian yaitu 150-200 gram. Tikus yang digunakan yaitu tikus putih jantan karena tikus putih jantan tidak dipengaruhi oleh siklus hormonal (siklus reproduksi), serta daya tahan tubuh tikus putih jantan lebih kuat dibandingkan dengan tikus putih betina (Prasetya, 2012).

Penimbangan berat badan tikus putih Rattus norvegicus dilakukan setiap satu minggu sekali yang bertujuan untuk mengevaluasi keseragaman berat badan, status gizi, dan kemungkinan adanya penyakit pada tikus putih selama penelitian. Penimbangan berat badan juga digunakan untuk penentuan dalam pemberian dosis (pemberian ekstrak etanol buah sirsak). Ratarata berat badan tikus selama 30 hari mengalami kenaikan menandakan tikus putih tidak stres.

Pembuatan ekstrak menggunakan metode maserasi yang merupakan salah satu jenis ekstraksi padat cair yang paling sederhana. Proses ekstraksi dilakukan dengan merendam sampel menggunakan pelarut etanol $70 \%$, karena zat yang terkandung di dalam buah sirsak terdapat zat yang bersifat polar dan non polar sedangkan Pelarut mengandung zat kimia dan air sehingga zat yang terkandung di dalam buah sirsak dapat tertarik semua. Ekstrak kental yang sudah jadi sebanyak 3,27 gram.

\section{KESIMPULAN}

Berdasarkan hasil penelitian yang diperoleh, dapat ditarik kesimpulan bahwa pemberian ekstrak etanol buah sirsak dengan dosis sebesar $3,6 \quad \mathrm{mg} / 200 \mathrm{gBB} / \mathrm{hari}$ $3,6 \mathrm{mg} / \mathrm{kgBB} /$ hari selama 14 hari efektif dapat menurunkan kadar kolesterol LDL tikus hiperkolesterolemia. 


\section{DAFTAR PUSTAKA}

Abbas, S.I., Mohammed, T.A., Al-Mahdi RA. 2015. Identificatinon Ofanofof Some Annona murcicata L. (Soursop) Components and Their Antioxidant Effects in rats. The Iraqi Postgraduate Medical Journal, Vol. 14, No.4, 2015.

Anies. 2015. Kolesterol dan Penyakit Jantung Koroner: Solusi Pencegahan dari Aspek Kesehatan Masyarakat. Yogyakarta: Ar-Ruzz Media: 60.

Dharma, S., Supanda, O., Elisma. 2014. Pengaruh Ekstrak Etanol Daun Sirsak (Annona muricata L.) Terhadap Kadar LDL pada Tikus Putih Jantan.Jurnal Farmasi Hige, Vol. 6, No. 1, 2014.

Departemen Kesehatan RI. 2014. Situasi Kesehatan Jantung. Pusat Data dan Informasi, Jakarta Selatan.

Firmansyah D, Bachri MS, Nurkhasanah. 2016. Pengaruh Pemberian Ekstrak Etanol Dan Kloroform Daun Sirsak Terhadap Kolesterol Total Dan Trigliserida Pada Tikus Yang Diinduksi Aloksan, Pharmaciana, Vol. 6, No.1, 47-54, 2016

Hustomi, I. \& Sujayan A. 2011. Gempur Habis Ragam Penyakit dengan Sirsak. Cahaya Yogyakarta: Atma Pustaka: 2.

Kurniadi, H. \& Nurrahmani. 2014. Stop Gejala Penyakit Jantung Koroner, Kolesterol Tinggi, Diabetes Melitus, Hipertensi.Yogyakarta: Istana Media: 88-89.

Linder MC. 2010. Biokimia Nutrisi dan Metabolisme. Jakarta: UI Press: 597.

Nilawati S, Krisnatuti D, Mahendra B, Djing OG. 2008. Care Yourse If Cholesterol. Jakarta:Penebar Plus:9.

Posangi I, Posangi J, Wuisan J, 2012 Efek Ekstrak Daun Sirsak (Annona Muricata L.) Pada Kadar Kolesterol Total Tikus Wistar. Jurnal Biomedik. Vol. 4, No. 1.

Prasetya H. 2012. Peluang Jitu Berternak Tikus Putih. Yogyakarta:Baru Press: 77.

Rahman H, Arifin H, Dewi GK, Rizal Z. 2014. Pengaruh Pemberian Buah Sirsak (Annona muricata L.) Terhadap Kadar Asam Urat Darah Mencit Putih Jantan Hiperuresemia. Prosiding Seminar Nasional dan
Workshop.Sekolah Tinggi Ilmu Farmasi, Padang.

Risky IS, Kusharyanti I, dan Handini M. 2014. Uji Efek Ekstrak Etanol 70\% Daun Bawang Kucai (Allium Tuberosum Rottl. Ex Spreng) Terhadap Penurunan Low Density Lipoprotein (LDL) Serum Tikus Putih Jantan (Rattus Norvegicus) Galur Wistar.Naskah Publikasi, Universitas Tanjung Pura Pontianak.

Rofida S, Firdiansyah A, Fitriyastuti E, 2015 Aktivitas Antihiperlipidemia Ekstrak Etanol Daun Annona squamosa L. Journal of Pharmaceutical Science And Pharmacy Practice. Vol 2, No.1, 2015.

Tia HD, Sistiyono, Hendarta NY. 2014. Pengaruh Berbagai Dosis Jus Buah Sirsak (Annona muricata L.) Terhadap Penurunan Kadar Kolesterol Low Density Lipoprotein (LDL) Serum Tikus Putih (Rattus norvegicus) Dislipidemia. Jurnal Teknologi Laboratorium. Volume 3 Nomor 2 tahun 2014.

Uneputty JP, Yamlean PVY, Kojong NS. 2013. Potensi Infusa Daun Sirsak (Annona Muricata L.) Terhadap Kadar Kolesterol Darah Tikus Putih Jantan (Rattus Novergicus). PHARMACON Jurnal Ilmiah Farmasi UNSRAT Vol. 2 No. 02, 2013.

Winarsi H. 2009. Antioksidan Alami dan Radikal Bebas. Yogyakarta: Kanisius: 19, 177, 178.

Wurdianing I, Nugraheni SA, Rahfiludin Z, 2014, Efek ekstrak daun sirsak (Annona muricata Linn) terhadap profil lipid tikus putih jantan (Rattus Norvegicus). Jurnal Gizi Indonesia. Vol 3.No.1, 2014.

World Health Organization (WHO). 2001. General Guidelinerfor Methodologies on Reasearch and Evaluation of Traditional Medicine. Genava.

Yuniarti L, Dewi MK, Lantika UA, Bhatara T. 2016.Potensi Ekstrak Air Daun Sirsak Sebagai Penurun Kolesterol dan Pengendali Bobot Badan. Acta Veterinaria Indonesiana. Vol. 4, No. 2: 82-87, Juli 2016. 